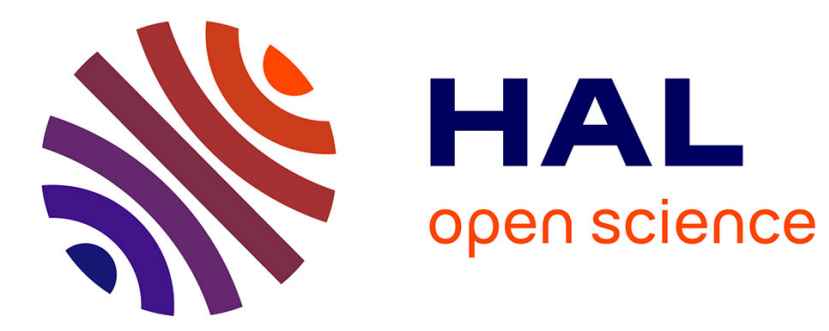

\title{
Triple Stack of a Viologen Derivative in a CB[10] Pair
}

Fengbo Liu, Shagor Chowdhury, Roselyne Rosas, Valérie Monnier, Laurence

Charles, Hakim Karoui, Didier Gigmes, Olivier Ouari, Floris Chevallier, Christophe Bucher, et al.

\section{- To cite this version:}

Fengbo Liu, Shagor Chowdhury, Roselyne Rosas, Valérie Monnier, Laurence Charles, et al.. Triple Stack of a Viologen Derivative in a CB[10] Pair. Organic Letters, 2021, 10.1021/acs.orglett.1c00773 . hal-03227458

\section{HAL Id: hal-03227458 https://hal-amu.archives-ouvertes.fr/hal-03227458}

Submitted on 17 May 2021

HAL is a multi-disciplinary open access archive for the deposit and dissemination of scientific research documents, whether they are published or not. The documents may come from teaching and research institutions in France or abroad, or from public or private research centers.
L'archive ouverte pluridisciplinaire HAL, est destinée au dépôt et à la diffusion de documents scientifiques de niveau recherche, publiés ou non, émanant des établissements d'enseignement et de recherche français ou étrangers, des laboratoires publics ou privés. 


\title{
Triple stack of a viologen derivative in a $\mathrm{CB}[10]$ pair.
}

\author{
Fengbo Liu, ${ }^{\mathrm{a}}$ Shagor Chowdhury, ${ }^{\mathrm{b}}$ Roselyne Rosas, ${ }^{\mathrm{c}}$ Valérie Monnier, ${ }^{\mathrm{c}}$ Laurence Charles, ${ }^{\mathrm{d}}$ Didier \\ Gigmes, ${ }^{\mathrm{d}}$ Olivier Ouari, ${ }^{\mathrm{d}}$ Floris Chevallier, ${ }^{\mathrm{b}}$ Christophe Bucher, ${ }^{*}$ Anthony Kermagoret, ${ }^{\mathrm{d}^{*}}$ Simin \\ Liu, ${ }^{\mathrm{a}^{*}}$ and David Bardelang. ${ }^{\mathrm{d}^{*}}$
}

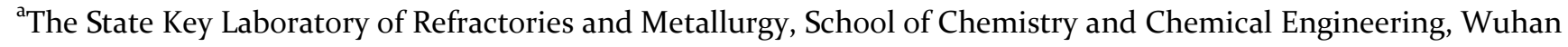
University of Science and Technology, Wuhan 430081, China.

${ }^{\text {b }}$ Université de Lyon, École Normale Supérieure de Lyon, CNRS UMR 5182, Laboratoire de Chimie, 46 allée d'Italie, F69364 Lyon, France

${ }^{c}$ Aix Marseille Univ, CNRS, Spectropole, FR 1739, Marseille, France

${ }^{\mathrm{d}}$ Aix Marseille Univ, CNRS, ICR, Marseille, France

Supporting Information Placeholder

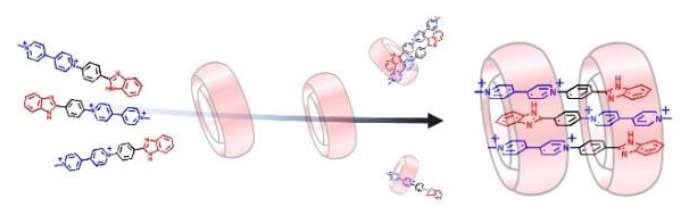

\begin{abstract}
A viologen-phenylene-imidazole (VPI) conjugate, previously shown to be singly complexed by $\mathrm{CB}[7]$ and doubly bound by $\mathrm{CB}[8]$ is herein shown to form antiparallel triple stacks in water with cucurbit[10]uril (CB[10]), pairwise complexing the guest trimer. The quinary host:guest 2:3 complex showed features assignable to charge transfer interactions. In reductive conditions, $\mathrm{CB}[10]$ could solubilize a VPI radical, even if $\mathrm{CB}[10]$ and reduced VPI are almost insoluble, thereby illustrating a possible new application for $\mathrm{CB}[10]$.
\end{abstract}

Supramolecular oligomers of controlled size and structure are key intermediates that are the subject of intense research work. For example, misfolded protein aggregates are involved in neurodegenerative diseases. ${ }^{1}$ Likewise in materials science, supramolecular oligomers are highly sought after because new physicochemical properties can emerge from a particular oligomer size/structure, with implications in fields as diverse as organic electronics, ${ }^{2}$ magnetic systems, ${ }^{3}$ or sensing. ${ }^{4}$ Controlling the organization of building-blocks in self-assembled oligomers is thus fundamental to tune and exploit their properties (i. e. electron conductance, ${ }^{5}$ electron spin, ${ }^{6}$ or photophysics). ${ }^{7}$ However, isolating well-defined oligomers remains a challenging task, ${ }^{8}$ mainly due to minor property differences between large oligomers and polymers. ${ }^{9}$ To design such oligomers, the following parameters are often considered: (i) their size, and (ii) the distance, (iii) the orientation and (iv) the kind of interaction between each unit. ${ }^{10}$ Besides the covalent approach often involving tedious syntheses and purifications, ${ }^{5,10}$ supramolecular chemistry enabled to get new stable oligomers, mainly by sequestering guest compounds in molecular cages ${ }^{10}$ of varying size and complexity."
In this context, container-shape macrocycles have received special attention owing to their ability to host two guests arranged either head to head or head to tail. ${ }^{12}$ Recently, the use of cucurbit $[n]$ urils $(\mathrm{CB}[n])^{13}$ has allowed to increase the size and diversity of oligomeric host:guest complexes, by using $\mathrm{CB}[8]$ to host two guest fragments. ${ }^{8 \mathrm{~b}}$ This strategy has allowed to tune the emission of fluorescent guests, ${ }^{14}$ to promote energy transfer through carefully positioned homo- and heterodimers, ${ }^{15}$ and to access well-defined cyclic oligomers. ${ }^{8 b}$ However, stacking more than two guests in $\mathrm{CB}[n]$ is not trivial. With its largest cavity in the $\mathrm{CB}$ family, ${ }^{16}$ cucurbit[1o]uril ${ }^{17}(\mathrm{CB}[10]$, Figure 1a) can complex large guests like a porphyrin, ${ }^{18}$ ruthenium complexes ${ }^{19}$ large dyes, ${ }^{20}$ or triple stranded helicates. ${ }^{21}$ With smaller guests, double stacking is observed in $\mathrm{CB}[10]$ enabling to control photodimerization ${ }^{22}$ or to promote metal-metal interactions. ${ }^{23}$ Exploiting charge-transfer interactions between viologens and a naphtalene, three guests were assembled in a quaternary $\mathrm{CB}[10]$ Complex. $^{24}$ Here we show that two $\mathrm{CB}[10]$ can work in concert to stabilize a stacking of three polyaromatic compounds affording a quinary guest:host 3:2 complex. 
a)
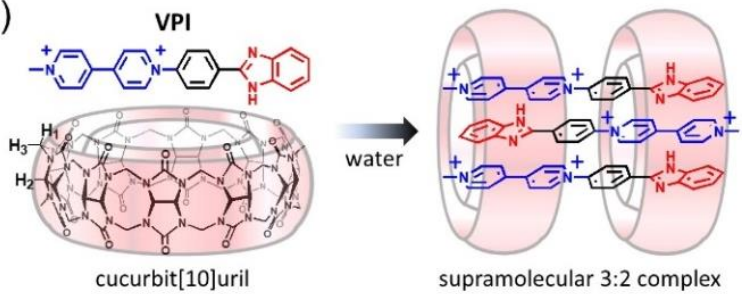

supramolecular 3:2 complex

b)

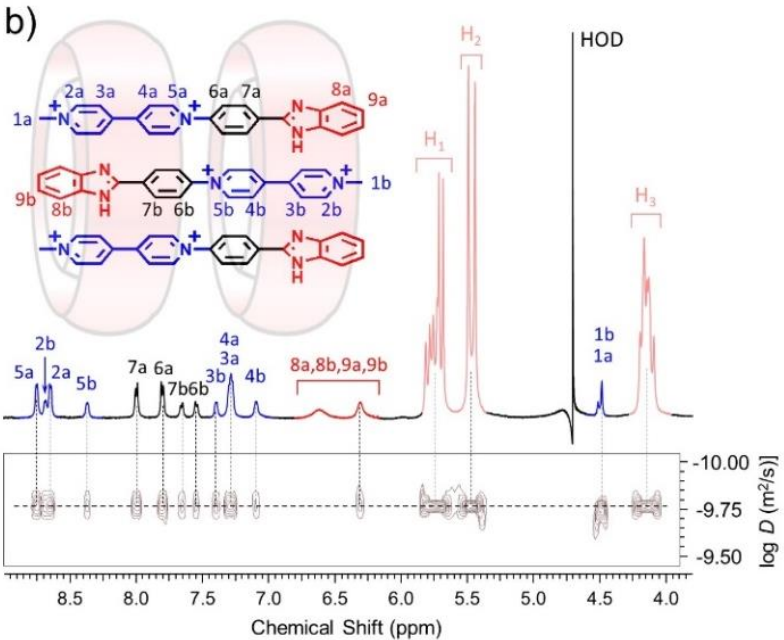

Figure 1. Molecular structures (a) of $\mathrm{VPI}^{2+}$ and of $\mathrm{CB}[10]$. Excerpt of the $500 \mathrm{MHz}{ }^{1} \mathrm{H}$ NMR spectrum (b) of the $\mathrm{VPI}^{2+}{ }_{3} \cdot \mathrm{CB}[10]_{2}$ complex $\left(0.167 \mathrm{mM}\right.$ in $\left.\mathrm{D}_{2} \mathrm{O}\right)$ and corresponding DOSY spectrum with proposed assignment.

The guest used in this work is a viologen-benzimidazole derivative ( $\mathbf{V P I}^{2+}$, Figure 1a) which was previously shown to form 1:1 complexes with $\mathrm{CB}[7]^{25}$ and 2:2 complexes with $\mathrm{CB}[8] .{ }^{26}$ In the latter case, two $\mathrm{VPI}^{2+}$ guests were found to adopt a head-to-tail arrangement to optimize electron donor/acceptor interactions in the two $\mathrm{CB}[8]$ cavities, significantly decreasing the basicity of the imidazole function in the $\mathbf{V P I}^{2+}{ }_{2} \cdot \mathrm{CB}[8]_{2}$ complex. ${ }^{26}$ The host ${ }^{27}$ and the guest (dichloride salt) ${ }^{25 \mathrm{~b}}$ were prepared according to previously reported procedures. ${ }^{1} \mathrm{H}$ NMR titrations increasing the host concentration afforded spectra with very broad signals in the aromatic region, up to approximately 1 equiv. of host (Table $\mathrm{S}_{1}$ and Figure $\mathrm{S} 1$ ). Near the host:guest equivalence, sharp resonances and upfield shifted signals were observed (Figure $1 \mathrm{~b}$ and Figure $\mathrm{S}_{2}$ ) and $2 \mathrm{D}$ spectra (Figures $\mathrm{S}_{3}$ to $\mathrm{S}_{4}$ ) confirmed inclusion of both the viologen and the benzimidazole moieties. The relative integration of ${ }^{1} \mathrm{H}$ NMR signals was consistent with formation of a 2:3 (H:G) complex. Interestingly, resonances corresponding to the central phenylene ring were found to split into two $A B$ patterns in a 2 to 1 ratio, suggesting two different environments for the guests. The observed 2/3-1/3 population suggests that at least $3 \mathbf{V P I}^{2+}$ molecules are involved in the $\mathrm{CB}[10]$ complex. The presence of three doublets assigned to $\mathrm{H} 1$ protons of $\mathrm{CB}[10]$ is consistent with three different environments for the carbonyl-fringed portals (Figure $\mathrm{S}_{5}$ ), a)
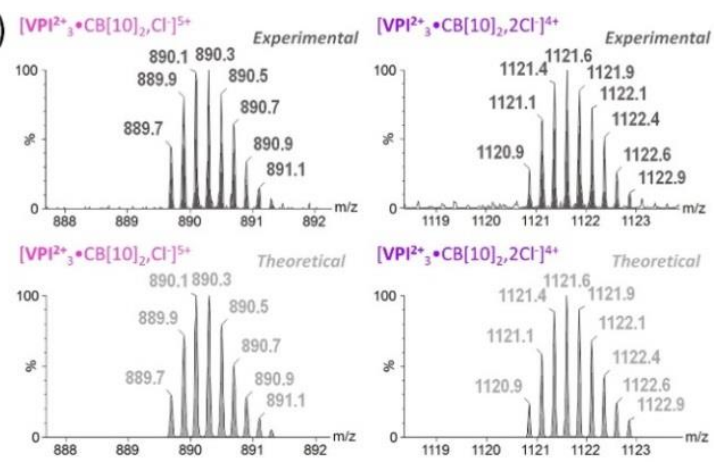

b)

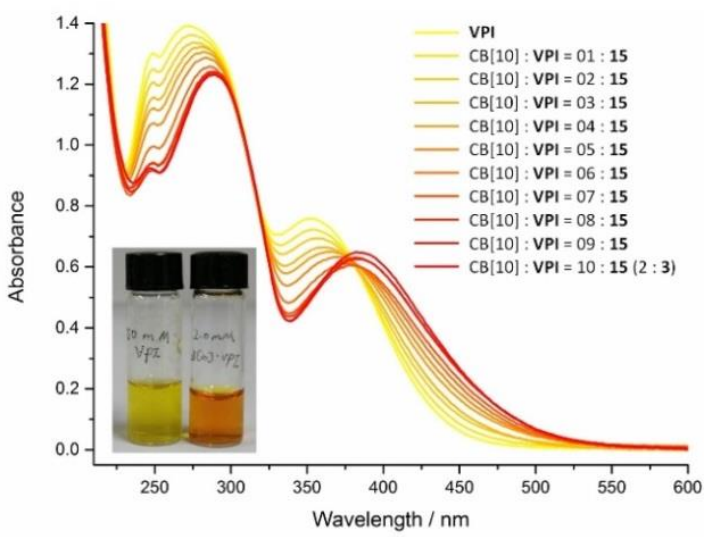

Figure 2. (a) Experimental and theoretical isotopic profiles for ions corresponding to $\left[\mathrm{VPI}^{2+}{ }_{3} \cdot \mathrm{CB}[10]_{2}, \mathrm{Cl}^{-}\right]^{5+}$ (left) and $\left[\mathrm{VPI}^{2+}{ }_{3}^{\bullet} \mathrm{CB}[10]_{2}, 2 \mathrm{Cl}^{-}\right]^{4+}$ (right). (b) UV-vis titration of VPI $^{2+}(90 \mu \mathrm{M})$ with $\mathrm{CB}[10]$ in water.

discarding the possibility of $1: 1$ or $2: 2$ complexes. NMR spectra are thus consistent with formation of a $2: 3 \mathrm{com}-$ plex in water, and DOSY experiments (Figure $1 \mathrm{~b}$ ) confirmed formation of a unique species diffusing at a lower speed $\left(D=1.78 \times 10^{-10} \mathrm{~m}^{2} . \mathrm{s}^{-1}\right)$ compared to VPI ${ }^{2+}$ alone $(D=$ $\left.4.68 \times 10^{-10} \mathrm{~m}^{2} . \mathrm{s}^{-1}\right) .^{26} \quad$ A hydrodynamic diameter of $23.5 \AA$ was obtained based on the Stokes-Einstein equation (assuming spherical approximation) that is consistent with the proposed structure. The $\mathrm{VPI}^{2+}{ }_{3} \cdot \mathrm{CB}[10]_{2}$ complex could be evidenced by electrospray ionization mass spectrometry, where it was observed at the +5 and +4 charge states including one or two chloride anions, respectively (Figure 2a and Figure S6). These assignments were further supported by accurate mass measurements, found to be consistent with elemental compositions $\mathrm{C}_{192} \mathrm{H}_{180} \mathrm{~N}_{92} \mathrm{O}_{40} \mathrm{Cl}^{5+}$ (Table S2) and $\mathrm{C}_{192} \mathrm{H}_{180} \mathrm{~N}_{92} \mathrm{O}_{40} \mathrm{Cl}_{2}{ }^{4+}$ (Table $\mathrm{S}_{3}$ ), and with relative errors below $5 \mathrm{ppm}$. Formation of $\mathrm{VPI}^{2+}{ }_{3} \mathrm{CB}[10]_{2}$ was further established from UV-vis absorption measurements carried out at different $\mathrm{H}: \mathrm{G}$ ratios (Figure $2 \mathrm{~b}$ and Table S4). Addition of increasing amounts of $\mathrm{CB}[10]$ to an aqueous solution of $\mathbf{V P I}^{2+}$ up to $\mathrm{H}: \mathrm{G}=1: 2$ led to an hypochromic and bathochromic shift $(+28 \mathrm{~nm})$ of the band centered at $352 \mathrm{~nm}$. NMR data suggest that the viologen and benzimidazole fragments, both included, could interact in the complex. The observed red shift could thus be due to an intermolecular charge transfer phenomenon between the benzimidazoles and the vio- 
logen moieties. ${ }^{28}$ Each donor group is stabilized by one or two acceptors and vice-versa. Yet, ${ }^{1} \mathrm{H}$ NMR and UV-vis titrations cannot exclude the existence of equilibria between supramolecular polymers and the discrete complex with $\mathrm{CB}[10]$. However, after reaching a 2 to 3 ratio, no more changes are observed, and the yellow color of the solution turned orange. Elemental analysis (supporting information) confirmed the proposed guest ${ }_{3}$ host $_{2}$ ratio since the observed $\mathrm{N} / \mathrm{C}$ ratio is equal to 0.563 , very close to the theoretical ratio of 0.559 for a 2:3 complex (Table $\mathrm{S}_{5}$ ) while the $\mathrm{N} / \mathrm{C}$ ratio for a 2:2 or a 3:3 complex would be o.611.

Efforts to get suitable single crystals of the complex remained unsuccessful. However, VPI was crystallized and the corresponding crystal structure (Table S6) showed a one-dimensional packing of $\mathbf{V P I}^{2+}$ molecules positioned head-to-tail, and characterized by a slight offset of $\pi-\pi$ overlaps for the four aromatic rings (Figure $3 \mathrm{a}$ ), and by distances between these rings of about 3.6-3.7 $\AA$, typical for $\pi$-stacked aromatic compounds. ${ }^{29}$ Insights into the structure of $\mathrm{VPI}^{2+}{ }_{3} \cdot \mathrm{CB}[10]_{2}$ were provided by DFT calculations. The minimized structure shown in Figure $3 \mathrm{~b}$ reveal (i) the existence of several guest:host $\mathrm{C}-\mathrm{H} \cdots \mathrm{O}$ bonds involving protons $2 \mathrm{a}, 2 \mathrm{~b}, 5 \mathrm{a}, 5 \mathrm{~b}, 6 \mathrm{a}, 6 \mathrm{~b}, 8 \mathrm{a}$ and $8 \mathrm{~b}$ (Figure $1 \mathrm{~b}$ for labelling) and oxygen atoms of the $\mathrm{CB}[10]$ carbonyl rims and (ii) distances between aromatic rings ranging from 3.5 to $4.3 \AA$.

While various techniques permitted to establish a $\mathrm{VPI}^{2+}{ }_{3} \cdot \mathrm{CB}[10]_{2}$ stoichiometry for the complex in solution, additional NOESY studies showed cross-peaks between the proton signals of $\mathrm{VPI}^{2+}{ }_{a}$ (labeled "a" in Figure $1 \mathrm{~b}$ ) and the proton signals of $\mathbf{V P I}^{2+}{ }_{b}$ (labeled "b" in Figure $\mathbf{1 b}$ ), highlighting a dynamic exchange between the two lateral $\mathbf{V P I}^{2+}$ guests and the central $\mathbf{V P I}^{2+}$ in $\mathrm{D}_{2} \mathrm{O}$. This exchange was confirmed by a series of ROESY experiments recorded at various mixing times (o to $700 \mathrm{~ms}, 300 \mathrm{~K}$, Figures $\mathrm{S}_{7}$ S11) to discriminate cross-peaks resulting from exchange from those coming from dipolar coupling. Exchange spectroscopy (2D EXSY) is a well-known technique to characterize dynamic systems for which exchange rates are comprised between $10^{-2}$ and $10^{2} \mathrm{~s}^{-1} \cdot 3^{30}$ Since $\mathrm{VPI}^{2+}{ }_{a}$ and $\mathbf{V P I}^{2+}{ }_{b}$ were assembled in the same complex $\mathbf{V P I}^{2+}{ }_{3} \cdot \mathrm{CB}[10]_{2}$, their apparent exchange equilibrium constant $K_{\text {app }}$ (equation eq 1 ) is $1 / 2$, as summarized in equation eq 2.

Using the EXSYCalc program ${ }^{31}$ and the different ROESY spectra recorded at $300 \mathrm{~K}$, we could estimate the magnetization exchange rate constants $k_{1}^{\prime}\left(0.52-1.55 \mathrm{~s}^{-1}\right)$ and $k_{-1}^{\prime}$ (1.04-3.85 s ${ }^{-1}$ ) for the $\mathbf{V P I}^{2+}{ }_{a}$ : VPI ${ }^{2+}{ }_{b}$ exchange (equation eq 1 and Tables $\mathrm{S}_{7}$ to $\left.\mathrm{S}_{11}\right)$ and apparent $K_{\text {app }}$ values between 0.58 and 0.29 , in relatively good agreement with the expected $K_{\text {app }}$ (eq 2).

$$
\begin{gathered}
\mathbf{V P I}^{2+}{ }_{a} \underset{k_{-1}^{\prime}}{\stackrel{k_{1}^{\prime}}{\rightleftarrows}} \mathbf{V P I}^{2+}{ }_{b} \\
K_{\text {app }}=\frac{k_{1}^{\prime}}{k_{-1}^{\prime}}=\frac{\left[\mathrm{VPI}^{2+}{ }_{b}\right]}{\left[\mathrm{VPI}^{2+}{ }_{a}\right]}=\frac{1}{2}
\end{gathered}
$$
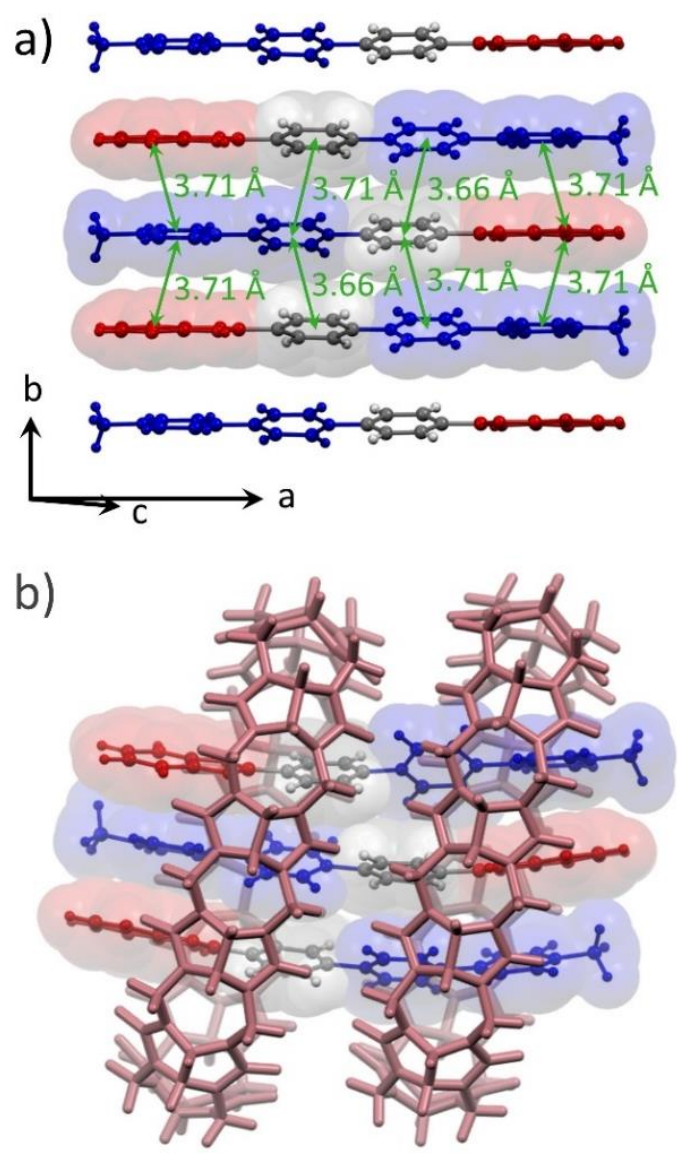

Figure 3. X-ray crystal structure (a) of $\mathbf{V P I}^{2+}$ alone (water molecules and chloride anions removed for clarity) and DFT minimized structure (b) of the $\mathrm{VPI}^{2+}{ }_{3} \cdot \mathrm{CB}[10]_{2}$ complex consistent with experimental data (see text).

Self-association of $\mathbf{V P I}^{2+}$ through donor-acceptor interactions in $\mathrm{CB}[10]$ was also supported by electrochemical measurements in water. As showed in Figure 4a (dashed line), the cyclic voltammogram of $\mathbf{V P I}^{2+}$ displayed a reversible wave attributed to the one-electron reduction of the viologen subunits $\left(\mathbf{V P I}^{2+} \rightarrow \mathbf{V P I}{ }^{+\bullet}\right)$. This wave features an ill-defined Gaussian-shape reoxydation peak assigned to the redissolution of radicals adsorbed at the electrode surface during the forward scan. Addition of $\mathrm{CB}[10]$ (Figure $4 \mathrm{a}$, full line) led to significant changes including i) a negative shift of the reduction wave in line with viologen units electron enriched and ii) a disappearance of the anodic redissolution peak suggesting that the inclusion of VPI $^{2+}$ precludes its adsorption at the electrode surface. These changes contrast with those observed for dimethyl viologen for which the addition of $\mathrm{CB}[10]$ does not cause significant changes (Figure S12). These results are consistent with the inclusion of $\mathbf{V P I}^{2+}$ in $\mathrm{CB}[10]$, and with a significant decrease in the electron-acceptor character of viologens resulting from the formation of intermolecular donor-acceptor complexes involving a partial transfer of electronic charge from the donor (benzimidazole) to the acceptor (viologen). 

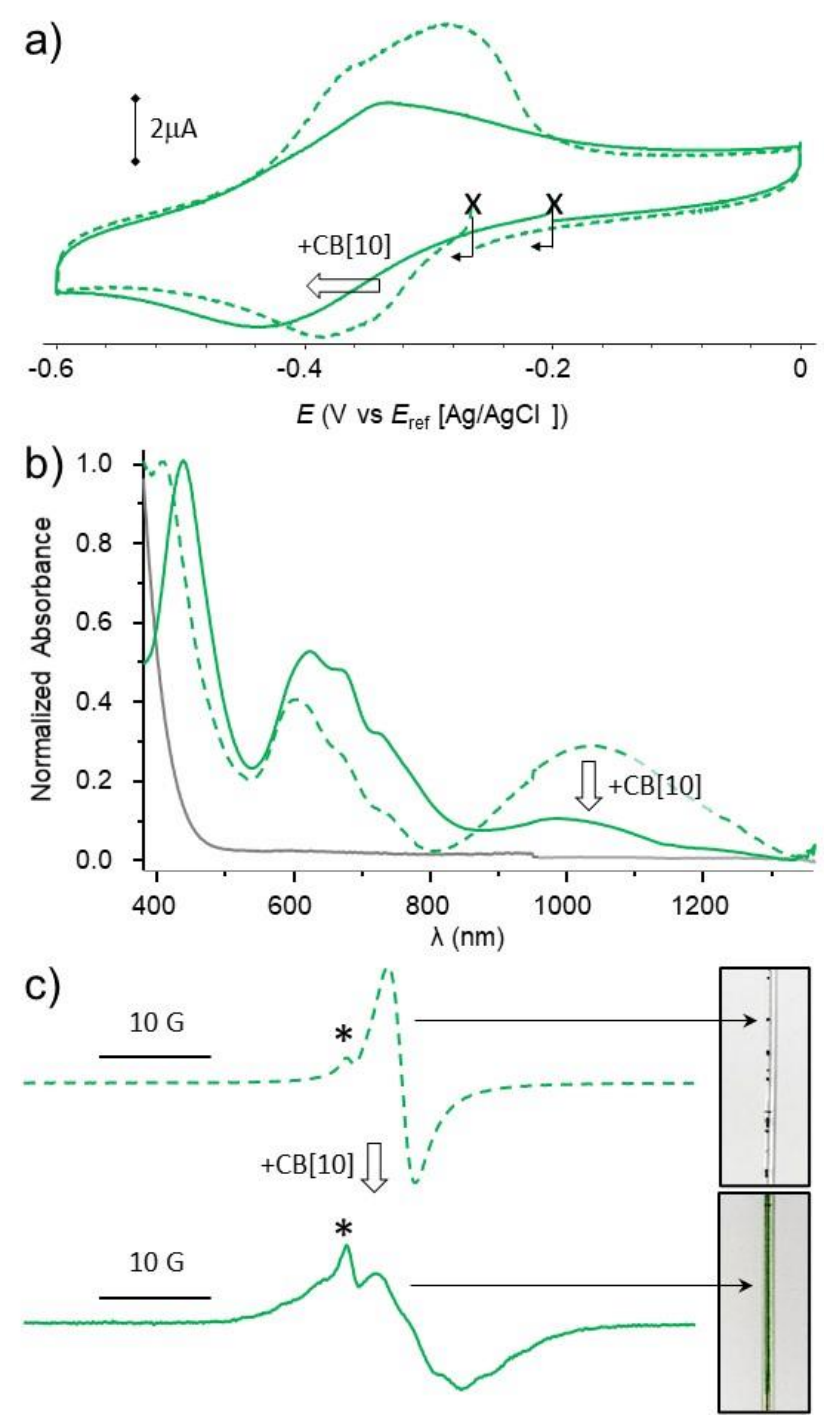

Figure 4. CV curves (a) for an aqueous solution of VPI (5 $\times 10^{-4} \mathrm{M}$ ) before (dashed line) and after (full line) addition of 1.1 equiv. of $\mathrm{CB}[1 \mathrm{O}]([\mathrm{LiCl}]=0.1 \mathrm{M}$, vitreous carb. $\varnothing=3$ $\mathrm{mm}$, E vs Ag+/Ag, v = 0.25 V.s ${ }^{-1}$ ). (b) UV-Vis absorption spectra with excess $\mathrm{Na}_{2} \mathrm{~S}_{2} \mathrm{O}_{4}$, of a VPI solution $\left(1.6 \times 10^{-4}\right.$ $\mathrm{M}, \ell=1 \mathrm{~mm}$, dashed line) and with 1.1 equiv. of $\mathrm{CB}[10]$ (full line; VPI spectrum: grey line). EPR spectra (c) corresponding to a reduced VPI solution $\left(5 \times 10^{-4} \mathrm{M}\right.$, top) and with 1.1 equiv. of $\mathrm{CB}[10]$ (bottom; * : residual signal of dithionite radical; the large signal on the top spectrum mainly corresponds to the solid product showed in the top inset).

Further insights into the structure of the inclusion complex formed after one electron reduction (on electron per viologen) of the $\mathrm{CB}[10]$-stabilized charge transfer complex $\mathrm{VPI}^{2+}{ }_{3} \mathrm{CB}[10]_{2}$ were obtained from in-situ absorption spectroscopy measurements. The dashed line absorption spectrum of Figure $4 \mathrm{~b}$ was recorded after addition of sodium dithionite as chemical reductant, ${ }^{32}$ to an aqueous solution of $\mathbf{V P I}^{2+}$. In agreement with previous works on viologen derivatives, ${ }^{33}$ the broad absorption band cen- tered at about $1050 \mathrm{~nm}$ together with the intense band at $600 \mathrm{~nm}$ are unambiguously assigned to the formation of $\pi$-dimers resulting from the self-association of two $\mathbf{V P I}^{\bullet}$ molecules into diamagnetic, sandwich-shape bimolecular complexes $\left[\left(\mathbf{V P I}^{+\bullet}\right)_{2}\right]_{\text {dim }}^{2+}$, stabilized by tight pairing of viologen units. In contrast to bipyridinium radical cationincorporated polymers, ${ }^{34}$ chemical reduction of the $\mathrm{VPI}^{2+}{ }_{3} \cdot \mathrm{CB}[10]_{2}$ complex revealed that $\mathrm{CB}[10]$ hampered the $\pi$-dimerization of the viologen-based radicals as reflected by the large decrease in the intensity of the $\pi$-dimer band observed in the near IR domain (full line spectrum of Figure 4b) and by the concomitant development of a set of transitions between 650 and $800 \mathrm{~nm}$ assigned to "free" viologen radicals. ${ }^{35}$ Finally, EPR spectroscopy of a VPI solution with excess sodium dithionite showed a large signal in the region expected for a reduced viologen that is mainly assigned to aggregates (Figure 4c, top, and Figure S13). In stark contrast, reduction of the $\mathrm{VPI}^{2+}{ }_{3} \cdot \mathrm{CB}[10]_{2}$ complex afforded a green, paramagnetic solution (Figure 4c, bottom). Even if the structure of $\mathbf{V P I}^{+\bullet}$ with $\mathrm{CB}[10]$ remains unclear, these data confirm the existence of host:guest interactions enabling to solubilize a paramagnetic form of VPI, while both $\mathrm{CB}[10]$ and $\mathbf{V P I}^{+\bullet}$ are poorly soluble in water.

In summary, three guests were constrained and directionally arranged using a pair of $\mathrm{CB}[10]$. The $\mathrm{VPI}^{2+}{ }_{3} \cdot \mathrm{CB}[10]_{2}$ complex showed a guest arrangement of "head-tail-head" type with dynamic exchange in water. While $\mathbf{V P I}^{2+}$ led to paramagnetic aggregates and few diamagnetic dimers after reduction, $\mathrm{CB}[10]$ had a benefic effect in maintaining paramagnetic $\mathbf{V P I}^{+\bullet}$ radicals in solution. We think that many other guests can form this new supramolecular 3:2 pattern with $\mathrm{CB}[10]$ and their properties studied as stacked trimeric assemblies, like fluorescent dyes, ${ }^{14-15}$ or fragments directing assembly toward supramolecular gels or supramolecular open frameworks. ${ }^{36}$

\section{ASSOCIATED CONTENT}

\section{Supporting Information}

Preparation and characterization of the $\mathrm{VPI}_{3} \cdot \mathrm{CB}[10]_{2}$ complex, $1 \mathrm{D}$ - and $2 \mathrm{D}$-NMR spectra, mass spectrometry measurements, and details of UV-vis spectroscopy measurements, elemental

analysis, and DFT calculations can be found in supporting information. CCDC number for the single crystal X-ray structure: CCDC-2057312. The Supporting Information is available free of charge on the ACS Publications website.

\section{AUTHOR INFORMATION}

\section{Corresponding Authors}

*E-mail: christophe.bucher@ens-lyon.fr

*E-mail: anthony.kermagoret@univ-amu.fr

*E-mail: liusimin@wust.edu.cn

*E-mail: david.bardelang@univ-amu.fr

Notes

The authors declare no competing financial interest. 


\section{ACKNOWLEDGMENT}

Financial support from the Overseas Scholarship Program for Graduate Students by the Wuhan University of Science and Technology (WUST) is gratefully acknowledged. CNRS, NSFC (21871216) and Aix-Marseille Université are acknowledged for financial and experimental supports. Pr. Didier Siri is gratefully acknowledged for advices about DFT calculations.

\section{REFERENCES}

(1) Soto, C.; Pritzkow, S. Nat. Neurosci. 2018, 21, 1332.

(2) Leclère, P.; Surin, M.; Viville, P.; Lazzaroni, R.; Kilbinger, A. F. M.; Henze, O.; Feast, W. J.; Cavallini, M.; Biscarini, F.; Schenning, A. P. H. J.; Meijer, E. W. Chem. Mater. 2004, 16, 4452.

(3) Ono, K.; Yoshizawa, M.; Akita, M.; Kato, T.; Tsunobuchi, Y.; Ohkoshi, S.-i.; Fujita, M. J. Am. Chem. Soc. 2009, 131, 2782.

(4) Suzuki, A.; Akita, M.; Yoshizawa, M. Chem. Commun. 2016, 52, 10024 .

(5) Schneebeli, S. T.; Kamenetska, M.; Cheng, Z.; Skouta, R.; Friesner, R. A.; Venkataraman, L.; Breslow, R. J. Am. Chem. Soc. 2011, 133, 2136.

(6) Combes, S.; Tran, K. T.; Ayhan, M. M.; Karoui, H.; Rockenbauer, A.; Tonetto, A.; Monnier, V.; Charles, L.; Rosas, R.; Viel, S.; Siri, D.; Tordo, P.; Clair, S.; Wang, R.; Bardelang, D.; Ouari, O. J. Am. Chem. Soc. 2019, 141, 5897.

(7) Wang, J.; Huang, Z.; Ma, X.; Tian, H. Angew. Chem., Int. Ed. 2020, 59, 9928.

(8) (a) Hunter, C. A.; Tomas, S. J. Am. Chem. Soc. 2oo6, 128, 8975. (b) Yang, X.; Wang, R.; Kermagoret, A.; Bardelang, D. Angew. Chem. Int. Ed. 2020, 59, 21280.

(9) Correia, H. D.; Chowdhury, S.; Ramos, A. P.; Guy, L.; Demets, G. J.-F.; Bucher, C. Polym. Int. 2019, 64, 572.

(10) Klosterman, J. K.; Yamauchi, Y.; Fujita, M. Chem. Soc. Rev. 2009, 38, 1714.

(11) (a) Yamashina, M.; Tanaka, Y.; Lavendomme, R.; Ronson, T. K.; Pittelkow, M.; Nitschke, J. R. Nature 2019, 574, 511. (b) Yoshizawa, M.; Nakagawa, J.; Kumazawa, K.; Nagao, M.; Kawano, M.; Ozeki, T.; Fujita, M. Angew. Chem., Int. Ed. 2005, 44, 1810. (c) Maurizot, V.; Yoshizawa, M.; Kawano, M.; Fujita, M. Dalton Trans. 2oo6, 275o. (d) Ono, K.; Yoshizawa, M.; Kato, T.; Fujita, M. Chem. Commun. 2008, 2328. (e) Osuga, T.; Murase, T.; Ono, K.; Yamauchi, Y.; Fujita, M. J. Am. Chem. Soc. 2010, 132, 15553.

(12) (a) Yang, C.; Mori, T.; Origane, Y.; Ko, Y. H.; Selvapalam, N.; Kim, K.; Inoue, Y. J. Am. Chem. Soc. 2008, 130, 8574. (b) Ikeda, H.; Nihei, T.; Ueno, A. J. Org. Chem. 2005, 7o, 1237. (c) Pattabiraman, M.; Natarajan, A.; Kaanumalle, L. S.; Ramamurthy, V. Org. Lett. 2005, 7, 529. (d) Di Costanzo, L.; Geremia, S.; Randaccio, L.; Purrello, R.; Lauceri, R.; Sciotto, D.; Gulino, F. G.; Pavone, V. Angew. Chem., Int. Ed. 2001, 40, 4245. (e) Kotturi, K.; Masson, E. Chem. Eur. J. 2018, 24, 8670. (f) Thompson, N. A.; Barbero, H.; Masson, E. Chem. Commun. 2019, 55, 12160 .

(13) (a) Lagona, J.; Mukhopadhyay, P.; Chakrabarti, S.; Isaacs, L. Angew. Chem., Int. Ed. 2005, 44, 4844. (b) Lee, J. W.; Samal, S.; Selvapalam, N.; Kim, H.-J.; Kim, K. Acc. Chem. Res. 2003, 36, 621. (c) Barrow, S. J.; Kasera, S.; Rowland, M. J.; del Barrio, J.; Scherman, O. A. Chem. Rev. 2015, 115, 12320. (d)
Assaf, K. I.; Nau, W. M. Chem. Soc. Rev. 2015, 44, 394. (e) Pazos, E.; Novo, P.; Peinador, C.; Kaifer, A. E.; García, M. D. Angew. Chem., Int. Ed. 2019, 58, 403. (f) Masson, E.; Ling, X.; Joseph, R.; Kyeremeh-Mensah, L.; Lu, X. RSC Adv. 2012, 2, 1213. (g) Hennig, A.; Nau, W. M. Monogr. Supramol. Chem. 2020, 28, 121. (h) Mikulu, L.; Michalicova, R.; Iglesias, V.; Yawer, M. A.; Kaifer, A. E.; Lubal, P.; Sindelar, V. Chem. - Eur. J. 2017, 23, 2350.

(14) (a) Olesińska, M.; Wu, G.; Gómez-Coca, S.; AntónGarcía, D.; Szabó, I.; Rosta, E.; Scherman, O. A. Chem. Sci. 2019, 10, 8806. (b) Wu, G.; Bae, Y. J.; Olesińska, M.; AntónGarcía, D.; Szabó, I.; Rosta, E.; Wasielewski, M. R.; Scherman, O. A. Chem. Sci. 2020, 11, 812.

(15) Wu, G.; Huang, Z.; Scherman, O. A. Angew. Chem., Int. Ed. 2020, 59, 15963.

(16) Yang, X.; Liu, F.; Zhao, Z.; Liang, F.; Zhang, H.; Liu, S. Chin. Chem. Lett. 2018, 29, 1560.

(17) (a) Day, A. I.; Blanch, R. J.; Arnold, A. P.; Lorenzo, S.; Lewis, G. R.; Dance, I. Angew. Chem., Int. Ed. 2002, 41, 275. (b) Liu, S.; Zavalij, P. Y.; Isaacs, L. J. Am. Chem. Soc. 2005, 127, 16798.

(18) (a) Liu, S.; Shukla, A. D.; Gadde, S.; Wagner, B. D.; Kaifer, A. E.; Isaacs, L. Angew. Chem., Int. Ed. 2oo8, 47, 2657. (b) Kubota, R.; Takabe, T.; Arima, K.; Taniguchi, H.; Asayama, S.; Kawakami, H. J. Mater. Chem. B 2018, 6, 7050.

(19) Luis, E. T.; Day, A. I.; Konig, B.; Beves, J. E. Inorg. Chem. 2020, 59, 9135 .

(20) Yao, Y.-Q.; Zhang, Y.-J.; Zhang, Y.-Q.; Tao, Z.; Ni, X.-L.; Wei, G. ACS Appl. Mater. Interfaces 2017, 9, 4076o.

(21) Hooper, C. A. J.; Cardo, L.; Craig, J. S.; Melidis, L.; Garai, A.; Egan, R. T.; Sadovnikova, V.; Burkert, F.; Male, L.; Hodges, N. J.; Browning, D. F.; Rosas, R.; Liu, F.; Rocha, F. V.; Lima, M. A.; Liu, S.; Bardelang, D.; Hannon, M. J. J. Am. Chem. Soc. 2020, 142, 20651.

(22) Hu, X.; Liu, F.; Zhang, X.; Zhao, Z.; Liu, S. Chem. Sci. 2020, $11,4779$.

(23) Kuang, S.; Hu, Z.; Zhang, H.; Zhang, X.; Liang, F.; Zhao, Z.; Liu, S. Chem. Commun. 2018, 54, 2169.

(24) Gong, W.; Yang, X.; Zavalij, P. Y.; Isaacs, L.; Zhao, Z.; Liu, S. Chem. - Eur. J. 2016, 22, 17612.

(25) (a) Cheng, Q.; Yin, H.; Rosas, R.; Gigmes, D.; Ouari, O.; Wang, R.; Kermagoret, A.; Bardelang, D. Chem. Commun. 2018, 54, 13825. (b) Yin, H.; Rosas, R.; Gigmes, D.; Ouari, O.; Wang, R.; Kermagoret, A.; Bardelang, D. Org. Lett. 2018, 20, 3187 .

(26) Yin, H.; Cheng, Q.; Rosas, R.; Viel, S.; Monnier, V.; Charles, L.; Siri, D.; Gigmes, D.; Ouari, O.; Wang, R.; Kermagoret, A.; Bardelang, D. Chem. - Eur. J. 2019, 25, 12552. 
(27) Yang, X.; Zhao, Z.; Zhang, X.; Liu, S. Sci. China: Chem. 2018, 61, 787 .

(28) (a) Ko, Y. H.; Kim, E.; Hwang, I.; Kim, K. Chem. Commun. 2007, 1305. (b) Biedermann, F.; Scherman, O. A. J. Phys. Chem. B 2012, 116, 2842.

(29) Salonen, L. M.; Ellermann, M.; Diederich, F. Angew. Chem., Int. Ed. 2011, 50, 4808.

(30) (a) Lu, J.; Ma, D.; Hu, J.; Tang, W.; Zhu, D. J. Chem. Soc., Dalton Trans. 1998, 2267. (b) Palmer, L. C.; Rebek, J. J. Org. Biomol. Chem. 2004, 2, 3051. (c) Asadi, A.; Ajami, D.; Rebek, J. Chem. Sci. 2013, 4, 1212.

(31) (a) MacMillan, S. N.; Hill Harman, W.; Peters, J. C. Chem. Sci. 2014, 5, 590. (b) https://mestrelab.com/.

(32) Tsukahara, K.; Wilkins, R. G. J. Am. Chem. Soc. 1985, 107, 2632.

(33) (a) Kahlfuss, C.; Grueber, R.; Dumont, E.; Royal, G.; Chevallier, F.; Cobo, S.; Saint-Aman, E.; Bucher, C. Chem. Eur. J. 2019, 25, 1573. (b) Chowdhury, S.; Nassar, Y.; Guy, L.; Frath, D.; Chevallier, F.; Dumont, E.; Ramos, A. P.; Demets, G. J.-F.; Bucher, C. Electrochim. Acta 2019, 316, 79.

(34) Qi, Q.; Yang, B.; Xi, C.-G.; Yang, X.; Zhang, D.-W.; Liu, S.; Li, Z.-T. ChemistrySelect 2016, 1, 6792.

(35) Abdul-Hassan, W. S.; Roux, D.; Bucher, C.; Cobo, S.; Molton, F.; Saint-Aman, E.; Royal, G. Chem. - Eur. J. 2018, 24, 12961.

(36) (a) Zhang, K.-D.; Tian, J.; Hanifi, D.; Zhang, Y.; Sue, A. C.-H.; Zhou, T.-Y.; Zhang, L.; Zhao, X.; Liu, Y.; Li, Z.-T. J. Am. Chem. Soc. 2013, 135, 17913. (b) Tian, J.; Zhou, T.-Y.; Zhang, S.C.; Aloni, S.; Altoe, M. V.; Xie, S.-H.; Wang, H.; Zhang, D.-W.; Zhao, X.; Liu, Y.; Li, Z.-T. Nat. Commun. 2014, 5, 5574. 